\title{
The enlargement process on hold? Comparison of the French and German positions towards the widening of the $\mathrm{EU}$
}

\section{Proces proširenja na čekanju? Poređenje pozicija Francuske i Njemačke prema proširenju $\mathbf{E} \mathbf{U}$}

\author{
Anes Makul \\ anes.makul@gmail.com
}

\begin{abstract}
This work aims to compare the enlargement policies of France and Germany, which are regarded as the leaders of the EU and whose policies are assumed to have a significant impact on other states within the Union. Additional to the political significance, these two countries are among the founding members of the Union and have been part of every of the seven enlargement rounds. Besides similarities, there is also a significant difference between these two states in their approach to the expansion of the EU. While France acts as an enlargement skeptic, Germany acts as a supporter of the widening process. The general hypothesis is that the enlargement policies of these two states are determined by the perceived costs and benefits of such policy.
\end{abstract}

Sažetak: Cilj ovog rade poređenje politika proširenja Francuske i Nemačke, koje se smatraju liderima EU i za čije se politike pretpostavlja da imaju značajan uticaj na druge države u Uniji. Pored političkog značaja, ove dvije zemlje su među članicama osnivačima Unije $i$ bile su dio svake od sedam rundi proširenja. Osim sličnosti, između ove dvije države postoji i značajna razlika u pristupu širenju EU. Dok Francuska nevoljko podržava politiku proširenja, njemačka pozicija je suprotna francuskoj. Opća hipoteza je da su politike proširenja ove dvije države određene percipiranom troškovima i benefitima takve politike.

Keywords: EU enlargement, France, Germany, Western Balkans, Euroscepticism

JEL Classification: F53

Article History

Submitted:29/11/2021

Accepted:31/12/2021

Ključne riječi: $p r \quad E U$ proširenje, Francuska, Njemačka, Zapadni Balkan, Euroskepticizam

Historija članka Dostavljen:29.11.2021

Prihvaćen:31.12.2021 


\section{INTRODUCTION}

The enlargement policy of the European Union is stalling. The Reuters news agency has confirmed this when they reported the intentions of four EU member states not to include a guarantee of membership in the final declaration of the EU summit to be held in Slovenia on 6 October 2021 (Emmott 2021). However, the membership perspective was included in the document, yet the development sheds new light on the enlargement process. The accession of new member states still represents a formal policy of the EU, but in recent years, there is growing skepticism within the European Union whether membership of Western Balkans ${ }^{1}$ states is realistic in a foreseeable future. The skeptical views reflect the policies of some EU members, whose support for the expansion remains rather on a rhetoric level. Contrary to skeptical views, some other states still support the enlargement policy. The decision to accept new states is dependent on the policy convergence of the member states because every state within the European Union must give consent to include a new country into the EU institutional framework.

This work aims to compare the enlargement policies of France and Germany, which are regarded as the leaders of the EU and whose policies are assumed to have a significant impact on other states within the Union. Additional to the political significance, these two countries are among the founding members of the Union and have been part of every of the seven enlargement rounds. Furthermore, these two countries have experienced similar political consolidation and economic growth and they have experienced similar challenges in the postwar period. However, "France and Germany have often displayed critical differences in their definitions of national interests and their foreign policy attitudes in general" (Krotz 2015, 2).

Besides similarities, there is also a significant difference between these two states in their approach to the expansion of the EU. While France acts as an enlargement skeptic, Germany acts as a supporter of the widening process.

Hence, this text intends to analyze the factors that affect the reluctance in the former and the support in the latter. The general hypothesis is that the enlargement policies of these two states are determined by the perceived costs and benefits of such policy. Following this logic, it is assumed that the position of France is determined by the perception that the costs of enlargement to Western Balkan states outweigh the benefits. German position towards enlargement is the opposite - the perceived benefits outweigh the costs.

Throughout the history of the EU, France has expressed its concerns regarding enlargement in every round, while its ability to follow the enlargement agenda has significantly been limited by the amendments to the Constitution in 2008 which foresee organizing of a referendum before accepting a new member state. Consequently, public opinion is a constraint for the widening because of reluctant French citizens towards the accession of new states. Furthermore, the enlargement skepticism is also rooted in French political parties. Compared to Germany, the economic relations between France and Western Balkans states are less pronounced. Furthermore, French politics has undergone a significant change including the appearance of the Eurosceptic right-wing populist National Front (National Rally) ${ }^{2}$ in mainstream politics. The upcoming French elections in 2022 pose an additional constraint due to the ability of the National Rally to raise an issue and make it public.

\footnotetext{
${ }^{1}$ Western Balkans include Albania, Bosnia and Herzegovina, Kosovo, Montenegro, North Macedonia and Serbia.

${ }^{2}$ National Front has changed its name in 2018 into Rassemblement national (National Rally)
} 
German enlargement policy characterizes the overall agreement for enlargement among the major political parties, which lasts for decades. Compared to France, the German enlargement policy is not bound to the formal will of the people, although public opinion polls suggest lower support than in France. Similar to France, the right-wing Eurosceptic political party Alternative for Germany has become part of the mainstream political arena in Germany, but with less effect on politics. On the other hand, economic interests play an important role in German enlargement policy, and foreign policy in general, although the assumption about the stabilizing role of the EU expansion prevails regarding Western Balkans.

This work consists of three chapters. The first chapter starts with a brief overview of the French enlargement policy. It proceeds then with an analysis of the current French enlargement policy towards Western Balkans. The second chapter follows the pattern of the first chapter. It starts with an overview of the German stand of enlargement policy. It continues with an analysis of the current German stand towards the expansion of the Union. The third chapter is devoted to the possible effects of the positions of these two states on the enlargement policy.

Standard Eurobarometer reports will be used to present the attitudes of people related to enlargement. These reports are published biannually over a longer period and therefore they provide a valuable source of information about the changes in attitudes related to various topics, including the support for enlargement. Official policy proposals and other official governmental and party documents will be used to indicate the positions of the states and actors involved in the decision-making process. Academic literature on EU enlargement and public opinion formation will also be used in this work. Besides mentioned sources, media reports are a valuable source of information that also will be used.

\section{FRENCH ENLARGEMENT POLICY}

\section{Overview of the main features}

The reluctance of the enlargement of the European Union is deeply rooted in French politics because France has always raised objections regarding the acceptance of new members under the European institutional framework. It did already start in the 1960s when the President of France at that time, Charles de Gaulle, rejected British membership in the European Economic Community. The decision not to include other states changed in the 1970s when a new president was elected and the first three states joined the Union. The only time, France did not raise any concerns regarding enlargement was in the case of Greece (Lippert 2007, 428).

Furthermore, the French position vis-à-vis Europe is rather based on deepening than on widening. This view was also expressed by French President Emmanuel Macron during his speech at the Sorbonne University in 2017 when he pledged for a stronger and more independent role of the EU as a global actor (Macron 2017). However, he did not reject the enlargement but made the expansion of the continent dependent on two factors. The first one is a more integrated and stronger Europe, and the second is the respect for "the acquis and democratic requirements" (Macron 2017, 22). The argument of making enlargement dependent on internal reforms in the Union represents a constant in French politics. Indeed, the developments in Western Balkans in the recent period show rather a democratic backsliding, which includes also a rise of authoritarianism (Bieber 2018). Consequently, the unresolved issues in any of the potential new member states would become a shared problem for the EU. 
At the same time, the impact of the EU on member states decreases significantly after the accession, because of great hurdles for imposing sanctions on rule violators.

Scholars have offered a variety of approaches regarding the French position towards enlargement. One explanation is that France is a "guardian of the idea of a political Europe" (Sjursen and Romsloe 2006, 144), which is based on the argument that French officials should be taken by their word when they define institutional changes as a precondition for the widening process (Sjursen and Romsloe 2006, 145-47). This approach rejects the „rhetoric entrapment“ argument offered by Schimmelfennig, who calls France „brakemen“ and explains the later consent for the widening of the French government as an avoidance to be rhetorically entrapped (Schimmelfennig 2005, 161-62). Krotz and Schild (2013, 152) label the French position towards enlargement as a „reluctant follower“.

Others argue that the French reluctant position reflects the low support among French citizens expressed in public opinion polls. This argument has already been used by French politicians in the 1990s to justify the positions they represent (Rieker 2005, 16-17). Other explanations suggest that one of the consequences of enlargement is a possible loss of power of France within the EU because of an increased number of members which leads to more power-sharing (Dursun-Ozkanca 2013, 253), while Skalnes (2005, 215) argues that membership of new states enables Germany to increase its power at cost of France. Indeed, it is a fact that Germany has mostly profited by enlargement due to its geographic proximity to East European states because of German economic reliance on exports. Wunsch $(2017,550)$ argues that the French position towards enlargement of Balkans states is based on a lack of economic and strategic interest in the region and the low support of the public opinion.

Despite Frech's reluctant position towards enlargement, the decision to enlarge has been interpreted in different ways. Firstly, the above-mentioned Schimmelfennig interpretation is that by not following the enlargement policy France would be entrapped, while other authors suggest that the support is the result of France avoiding isolation (Krotz and Schild 2013). Skanes $(2005,215)$ argues that enlargement to Eastern Europe was ,necessary to maintain French influence in Eastern Europe and prevent Germany from establishing a dominant position there."

The overview shows that the French position regarding enlargement suggests a lack of support for the acceptance of new states in the European Union, which is constant. The reluctant position has remained, yet the conditions in French politics have changed towards less acceptance for new member states in the European Union. In the next section, the current enlargement politics will be explored.

\section{The current French enlargement politics}

Widening is still the official policy of the European Union, yet its effectiveness is dependent on member states' policy convergence regarding this question. French skepticism towards enlargement remains constant, also towards the Balkans. Hence, the main question in this work is related to factors that impact that position. As it is argued, the position is determined by the perceived costs and benefits of enlargement. Consequently, the French reluctance is based on the assumption that the inclusion of Western Balkans states in the EU would be costlier compared to expected benefits. 
First, France is committed to a more integrated Union that includes also a stronger Europe as a significant actor at the international level. An increased number of states would make the decision-making process more complex, which leads to a more inefficient Union. Such development would also impact France and their ideas of a more integrated EU. These ideas foresee European defense structures, a common strategic culture, European Public Prosecutor's Office for organized crime and terrorism, cooperation on climate change, and a common approach to migration and asylum (Macron 2017, 4-7).

The French non - paper about the new enlargement methodology reiterated the official stand which makes widening dependent on internal reforms in the EU and the Balkans. The new methodology foresees a gradual accession process divided into seven stages and gradual participation of candidate states in policies after successful negotiations (French Government 2019). The document was criticized because the new methodology requires adjustments to accession negotiations. Yet, the limited success in the integration of Western Balkans states indicates that there was a need to make changes to trigger the process. On the other hand, it shows an inconsistent enlargement policy of the EU. Furthermore, Macron has argued that every enlargement has weakened the EU after France and Netherlands blocked the start of accession negotiations with Albania and North Macedonia in 2018 (Politico 2018). However, before the Prespa agreement, Macron has encouraged North Macedonia to change its name and to end a decade's long dispute.

Secondly, the constitutional changes in 2008 include a provision of holding a referendum regarding the membership of new states in the EU (Wunsch 2017, 545). However, this provision can be overridden if three-fifths of both houses of the French Parliament vote for the bill as it is defined in article 88-5 of the Constitution (French National Assembly 1958). Considering the low support among French citizens for enlargement, the results of an eventual referendum regarding the inclusion of new member states in the European Union are more likely to fail. The following chart includes results from the Standard Eurobarometer regarding French support and opposition to enlargement from 2008 to 2021.

\section{SUPPORT AND OPPOSITION TO ENLARGEMENT IN FRANCE}

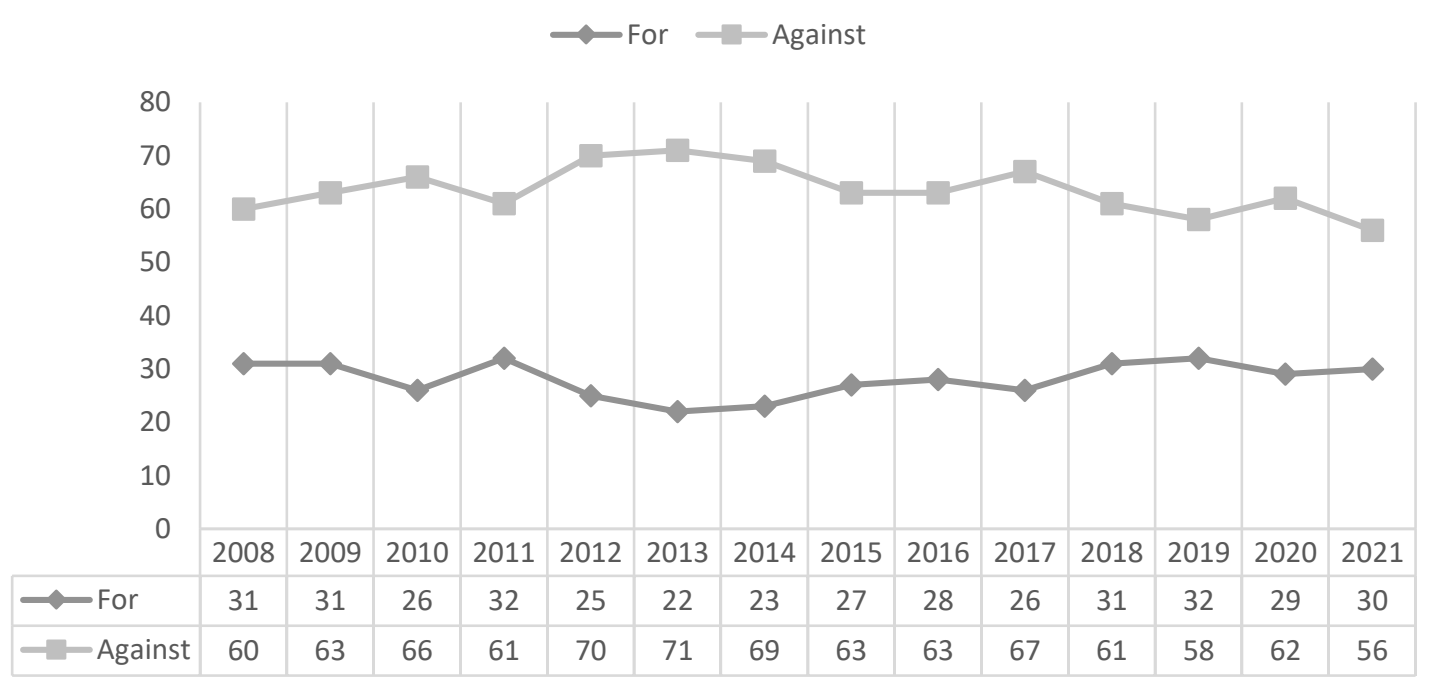


Figure 1: The data used are from the Standard Barometer reports and annexes of the reports $69,71,73,75,77,79,81,83,85,87,89,91,93,95 .^{3}$

The data from the chart indicate that the support for enlargement among French citizens is significantly lower compared to support. In the perceived period, the highest support has been recorded in 2011 and 2019, when 32\% of French citizens did not object to the membership of new states in the EU. The lowest values have been reported in 2013 and 2014. Furthermore, the values which show the highest opposition of French citizens have been recorded in 2012 and 2013. These are the periods when the economic and financial crises have reached their peak in the EU, which was followed by an increased distrust towards the European Union as public opinion data show (European Commission 2019, 5). Hence, the stand of French citizens can be observed as relatively stable over time which includes notable changes, yet these changes did not switch places.

Considering the data from the Eurobarometer reports, the threshold for the acceptance of new member states is quite high. In other words, the inclusion of the referendum into the French basic law has created an obstacle that is hard to overcome. The change of public opinion regarding enlargement can be explained by two factors. The first one is the type of information people receive from media about the process. If the information is positive, the attitude of people is more likely to change towards more acceptance of new members. If the information is neutral, it is more likely that a change of public opinion will not occur, while exposure to negative news about widening will likely affect the people to adopt a more negative stand which is expressed in lower support for the process (de Vreese and Boomgaarden 2006). The secondfactor impacting people's stand for enlargement is previous attitudes that might deepen preexisting stand, depending on the information they receive (Azrout, Van Spanje, and de Vreese 2012).

The stands of people regarding enlargement is a topic that could become a subject that the populist right-wing Eurosceptic National Rally can use to raise the question of enlargement in public and blame the current government to act against people's will. This follows the logic of Mudde's definition of populism. He defines populism as "an ideology that considers society to be ultimately separated into two homogeneous and antagonistic groups, 'the pure people' versus 'the corrupt elite', and which argues that politics should be an expression of the volonté générale (general will) of the people" (Mudde 2004, 543). The election campaign for the forthcoming French elections in 2022 has the potential to become an arena in which the government can be blamed to follow a policy that does not enjoy support among citizens. Namely, National Rally is a hard Eurosceptic party. These political parties do not support the enlargement of the EU (Kaniok and Hloušek 2016). Although National Rally does not have the institutional power to stop a process ${ }^{4}$, however, their potential is based on their ability to raise an issue in the public. As some studies suggest, there is a link between exposure to certain topics in the media and the success of political parties in the elections (Hameleers, Bos, and de Vreese 2017, 1). Hence, an unfavorable topic for the sitting government can affect the election outcome, "if people believe that the government is responsible, they are less likely to vote for it" (Hameleers, Bos, and de Vreese 2017, 3). One topic that appears to be unfavorable to a broader public is the large Muslim community in the Balkans. This is because of Islamophobia, which poses an important element in the politics of the National Rally (Zúquete 2016, 109). Furthermore, reports suggest an

\footnotetext{
${ }^{3}$ The reports and annexes are available at https://europa.eu/eurobarometer/surveys/browse/all/series/4961

${ }^{4}$ During the elections in 2017 Front National won 8 seats in the lower house of the French Parliament, which is an increase of 6 , compared to previous elections.
} 
increased Islamophobia in France which was marked by different government actions (Attalai and Moussi 2021).

The success of Marine Le Pen, the President of Front National (now National Rally), when she was a candidate in the second round of the Presidential elections and got 34 percent of votes, made the mainstream political parties more cautious when proposing new policies. This development applies even more to topics that appear unfavorable for a significant number of French citizens. Some authors argue that Front National has already reduced the scope of the French government to act on topics related to European politics (Münkler 2017, 114). The conditions under which the French Presidential and general elections will take place in 2022 are less likely to change towards a more welcoming politics regarding enlargement. According to polls, the current President Macron and Le Pen will be the candidates with the most votes, both in the first and the second round with a bigger chance of Macron becoming re-elected (Politico 2021). A few days ahead of the elections for the European Parliament in 2019 the former French minister for European Affairs Nathalie Loiseau even declared that she prevented the accession of Albania and North Macedonia (Süddeutsche Zeitung 2019). Although the French decision was to postpone the accession negotiations and not the accession, this statement can be understood as an adjustment to the French voter preferences.

Besides Euroscepticism that expresses National Rally, some of the mainstream parties have already used Eurosceptic topics in their campaign. During the 2012 Presidential elections, both candidates in the second round Nicolas Sarkozy from the Republican Party and Francois Hollande from the Socialist Party, have used Eurosceptic topics (Vassallo 2012). This can be understood as the adjustment to people's expectations, because of the distrust towards the EU that reached its peak in 2012 and 2013. At that time, Euroscepticism posed an issue for the whole Union because the EU was perceived by many rather as a trouble-maker. It was a novel situation, which the EU has not experienced before. That development had two effects. The first one was that it helped Eurosceptic parties to become part of mainstream politics. Their agenda was to a large extent based on criticizing the EU by arguing that they could not fight the negative effects of the crises effectively. The second development was that EU citizens have become more interested in EU matters. It was the transition from "permissive consensus to constraining dissensus" (Marks and Hooghe 2009). While before the crises EU citizens have shown little interest in the EU, the crises have increased their interest. Both developments have created pressure on traditional parties to adjust their positions to growing skepticism towards the European Union.

An additional factor that accounts for French reluctance towards enlargement is based on rather modest trade relations compared to Germany and other states in the region of Western Balkans and Italy (Pere and Ninka 2017, 77). France, has, however, increased its economic presence since 2019, when the French Development Agency started its program for Western Balkans with a portfolio of 450 million Euros. The program includes projects related to sustainable development and climate change (Agence Française de Développement 2021).

The major argument of this work is that the French reluctance regarding enlargement is based on the perceived costs and benefits of that policy. Hence, the French hesitant position is shaped by the assumption that following the widening policy is costlier compared to its benefits. The potential to increase the costs is primarily expressed in domestic politics. In other words, the current French government assumes that following a pro-active approach towards the inclusion of Western Balkan states into the EU makes the government more vulnerable to potential loss of power, or at least it leads to a significant decrease in power. Second, the modest economic 
relations between France and the Balkans do not have the potential to increase pressure on the French government to change its initial stand.

\section{GERMAN ENLARGEMENT POLICY}

\section{Overview of the main features of the German enlargement policy}

As one of the founding countries of the EU, Germany has always played an important role in shaping the Union, both in the deepening and the widening process. According to Bulmer $(2014,1248)$ "Germany is the most consistently pro-integrationist member State since the 1950s." The consistent position towards the EU is based on a common agreement of the major political parties whose support for further integration never has been questioned. Although France firmly supports the integration of the EU, by proposing an expansion of fields of cooperation at the EU level, the German pro - EU position differs to some extent. There have been repeated calls from German officials to create the United States of Europe. This was done by the first Head of the European Commission Walter Hallstein, but also later by Helmut Kohl, even he backed from his position. Joschka Fischer has used different wording when he proposed the creation of a European State during his mandate as the minister of foreign affairs (Große Hüttmann 2017, 34-39). The former Head of the European Parliament Martin Schulz declared the year 2025 to create the United States of Europe (Die Zeit 2017). The call to create a European state indicates that Germany is deeply supportive of the idea to strengthen the EU level of governance. This argument applies to the German foreign policy as well, because the EU is „the foundation of German foreign policy“ (Steinmeier 2015). The enlargement policy has also been a consistent part of German politics. Every German Chancellor since Willy Brandt till Angela Merkel has been part of the enlargement process (Lippert 2017, 393).

Participation in the EU has provided tangible benefits to Germany. Foremost, this applies to the German economy, because the creation of the single market and the enlargement has helped Germany to become the leading export country in the EU (Dreger 2017, 77), but also one of the world leaders. One decade after the 2004 enlargement, Germany has created one million new jobs as a consequence of the accession of ten new states (Focus Online 2014). The common market has expanded to ten new states and around 80 million new consumers have become part of the EU.

German position regarding enlargement was explained by different factors. Some scholars argue that German EU integration and enlargement policies during the mandate of Helmut Kohl were shaped by historic memories. The argument is that, by recalling historic memories, the role of the EU as a peace project was emphasized, which helped to legitimize the integration and the enlargement, while considering the state's interests as well (Banchoff 1997, 72-73). Others explain the EU enlargement process as of reconciliation, but also as a process in which German companies have profited (Jeřábek 2011, 94-100).

Schimmelfennig (2005) explains the German support for enlargement to Central and East European countries (CEEC) as the promise of enlargement given in the past in which the economic interests have been taken into account as well. Sedelmeier (2005) considers the promises about a future membership that the European Community has given to CEEC as crucial when the decision to expand was made. Some rationalist scholars argue that the German decision to support enlargement to CEEC was based on economic interests and geopolitical considerations (Moravcsik and Vachudova 2003). Skanes has argued that the German motive 
to support the expansion was based on geopolitics and to strengthen the German role within the $\mathrm{EU}$, but also as a war prevention tool to avoid wars like the one in former Yugoslavia in the 1990s (Skalnes, 2005).

Despite different interpretations about the motives of the German government to pursue the politics of the European expansion, the fact that all chancellors from Brandt to Merkel have been involved in the enlargement process explains the continuity of this policy. The official support for the enlargement of the Western Balkans states into the EU remains up to date. However, the conditions under which this policy can be followed have become more complex. The current position of the German government will be examined in the following section.

\section{The current German enlargement policy}

The German position regarding enlargement of the European Union policy differs to great extent compared to the French position. While France assumes that following the enlargement policy is costlier compared to expected benefits, the German position is the opposite. German enlargement policy towards Western Balkans states is based on the assumption that by not acting the situation would further destabilize. Hence, the crucial German argument is that the institutional embedding of the Balkans into the European Union reduces the conflict potential and helps preserve German and EU interests. In other words, any destabilization of the fragile peace in the Balkans would have immediate consequences on Germany (Toeglhofer and Adebahr 2017, 4) and the European Union.

The involvement of competing actors in the Balkans, such as Russia, China, Turkey, and Arab countries, are assumed to affect the EU interests, as the German Minister of State and Europe Michael Roth (2018) has stated. This assumption is based on fear of losing control of the European ,inner courtyard“ in the geopolitical dispute (Roth 2018). In particular, the German government defines Russia as a „challenge to security“ (German Federal Government 2016, 32).

Hence, the precondition to "defeat" the competing actors in the institutional binding of the Balkans to the EU. The German government expects that such development leads to mutually beneficial cooperation. Thus, the current support of the German government for the enlargement is based primarily on security.

However, the economic interests must be considered as well, which pose an important element of German foreign policy. Kundnani (2011) even labels Germany as a geo-economic power. His argument is based on the assumption is that German foreign policy is led by economic interests. Indeed, Germany is the biggest trade partner of Western Balkans states. The share of German exports is 16 percent of the overall exports to the Balkans, and at the same time, Germany imports 23 percent of all goods from the Balkans (European Commission 2018). The population size of the Western Balkans states is around 16 million (Eurostat 2021), which is, however, significantly lower compared to the population size of ten new countries that have become full members of the EU in 2004. The lower population size accounts for a smaller economic potential. Yet, a more stable region would lead to steady economic growth which increases the potential to benefit all actors involved.

The German stand regarding the European Union is to a large extent based on the perceived potential that the EU can bring to German interests. A strong European Union is needed as a tool for Germany to remain a global actor. The current German position as the fourth biggest 
economy in the world is likely to decline in the following decades because of the appearance of new powers. Thus, the best-perceived way to remain a global player and to preserve the German ability to act is a strong and wider EU (German Federal Government 2016, 22). The importance of this stand is even more emphasized by new challenges at the international level, such as climate change, pandemics, migrations, instabilities etc. So far, the EU's ability to act on a global scale remains limited because of the formal requirements regarding unanimous voting in the Council. This issue applies to the enlargement policy as well.

German domestic politics does not limit the actions of the national government to the same extent compared to France. There is a broad consensus among the traditional political parties to support the EU project and the EU enlargement. Germany has started two initiatives regarding enlargement in 2014. The first one is the Berlin Process, which has defined six goals to be achieved for the Western Balkans states (German Federal Government 2014), and the second one was a common initiative of Germany and the UK for a novel approach towards Bosnia and Herzegovina (Steinmeier and Hammond 2014).

The ruling parties in Germany from 2013 to 2021, SPD and CDU/CSU, made the enlargement part of their official agenda. During the 2013, 2017, and 2021 electoral campaigns, the Social Democratic Party (SPD) included the enlargement of the EU in their election manifestos (SPD 2013, 110, 2017, 99, 2021, 59). The Christian Democratic Union, along with its sister party, the Christian Social Union, have included the enlargement in their manifesto in 2013 (CDU/CSU 2013, 73), however, it was not included in the 2017 election manifesto. In 2021, the sister parties CDU/CSU supported the enlargement, making the accession process dependent on further integration of the EU (CDU/CSU 2021, 19). The Greens, the new partner in the 2021 government, also support the enlargement of the EU to the Western Balkans (Die Gruene 2021, 226). Support for enlargement was also included in the Coalition Treaty of 2021 (SPD/Gruene/FDP 2021, 136), although the Free Democratic Party (FDP) did not mention the enlargement in their manifesto. The right-wing populist Alternative for Germany (AfD) has changed its stand regarding enlargement. Their election manifesto in European elections in 2014 included the provision of a referendum concerning any new enlargements (Alternative für Deutschland 2014, 11), while their election manifesto in 2021 rejects enlargement at all. Instead of enlargement, they propose a privileged partnership as a stabilization tool (AfD 2021, 66). A privileged partnership was already proposed by Angela Merkel regarding Turkey, which excludes a membership. The left-wing political party Left did not include the EU enlargement in their manifesto. However, their critique of the EU relates to the capitalist character of the EU - they do not reject it.

Yet, the support of the traditional political parties is not unconditional. There are two important preconditions to be fulfilled to integrate new states into the EU. The first one is not new, since it includes a provision that foresees meeting the formal requirements defined in the Copenhagen criteria. This condition, however, has become more important in the recent period because of the democratic backsliding in Western Balkans states and further destabilization in the region. Without solving these issues, the internal problems of the Balkan states would become internal problems of the EU.

The second precondition defined by the German parties is the internal reform of the EU to increase their ability to act $^{5}$. This provision is related to foreign policy, and other fields as well, which is bound to a unanimous decision-making process. Although the majority of the German

\footnotetext{
${ }^{5}$ The German term of ,ability to act” is Handlungsfähigkeit, which is common in the manifesotos.
} 
parties do not mention clear ideas on how to improve the ability to act, the Greens propose changing the voting procedures in the EU. Instead of the unanimous voting procedure, their idea foresees the principle of majority voting (Die Gruene 2021, 226). In other words, because of the dependency on votes of all member states in the Council, the EU foreign policy remains rather inefficient. This has become clear in the second half of 2021 regarding an eventual imposition of sanctions on the member of the BiH Presidency Milorad Dodik, who undermines the constitutional structures of Bosnia and Herzegovina. The sanctions were proposed by the German government, but according to media reports, Hungarian and Slovenian governments refuse to vote for such a decision. Hence, the limitations in the foreign policy of the EU depart from the self-proclaimed goal of the EU to become a global policy shaper. The goal of a stronger Europe is defined in the EU Global Strategy (European External Action Service 2016).

The fact that all German parties in Bundestag, except the AfD, support the enlargement, reduces the potential to make the question of enlargement a polarizing issue. Second, the conditions under which the enlargement policy should take place overlap to a great extent. In short, the candidate countries must meet the requirements and the EU must reform. Some authors argue that the government must look always at the political right before deciding because of the risk of becoming a "lame duck" in European matters (Münkler 2017, 114). The AfD faction in Bundestag has already raised the question of the enlargement process in an inquiry to the executive. The question they raised was about the public opinion polls in which most citizens reject the accession of further states in the EU. It also contains a question of whether Germany plans to hold a referendum to accept new member states. The document included also questions about the Muslim religion in the Balkans and whether an eventual membership would affect the identities in Germany. The answers about the polls referred to polls that show that most citizens in the Balkans support the accession process. Second, the response regarding the referendum was that the German Constitution does not foresee a referendum regarding enlargement (Deutscher Bundestag, 2018).

The inquiry of the AfD reveals an eventual way of acting of that party concerning the widening process. Thus, they intend to use policies that appear unpopular to citizens and raise the issue in public by following the populist logic. The logic is to blame the government for acting against people's will, while at the same time presenting themselves as the defenders of that will. It is more likely for the strategy to be successful if the issue is salient. Salience means something that is "noticeable, meaningful, or memorable to audiences". Thus, the real potential for the AfD to capitalize on this issue is during the time of advanced accession negotiations, because of the increased attention of the particular topic.

In short, the result of the German calculation concerning enlargement is that the inclusion of Western Balkan states in the European Union is more beneficial for all actors involved. The stand is mainly based on the assumption that enlargement brings peace and stability to new member states. Domestic politics does not pose a significant obstacle for such policy. Although most of the German citizens refuse the accession of further states, there is no constitutional provision of a referendum. The following section will analyze the effects of the policies on Western Balkans.

\section{THE EFFECTS OF THE MEMBER STATES POLICIES}

The European Union has enlarged seven times so far. It is still assumed as the most successful foreign policy achievement of the EU. However, after the 2004 expansion, the internal dynamic 
has been affected. The increased number of member states has caused some changes. First, the lack of a suitable legal framework made the already complex decision-making process, even more, complex. This was mainly because of the failed referendums in France and the Netherlands regarding a European constitution. Second, the accession of new member states, of which eight were new democracies, required institutional adjustments, but also an adjustment of the old and the new members to each other. This is also the time when enlargement fatigue has occurred. It refers to "unwillingness to grant the EU membership to new States" (Szołucha 2010, 1).

The enlargement fatigue did not, however, stop the widening process, because of the memberships of Bulgaria and Romania in 2007, and Croatia in 2013.

After Croatia joined the EU, the accession of new member states has become more difficult. Developments in the EU and the region of Western Balkans have changed significantly. The internal crises in the EU, which have been affected by the global financial and economic crises led to increased Euroscepticism. The existence of the European Union has been questioned daily by populist political parties, whose electoral success moved them from the margins to the political mainstream. The success did not allow the populist Eurosceptic parties to formally block the processes in the EU, but their ability to raise certain issues in public, that appear unfavorable to a great number of EU citizens gave them substantial power to impact politics. This impact led eventually to a readjustment of positions of some traditional political parties. The response of some of these parties to this development was also Euroscepticism (Topaloff 2017, 63).

The focus of the European Union was to tackle the negative effects of the crises, or as the former Head of the European Commission Jose Manuel Barroso said "It is only natural that, over the last few years, our efforts to overcome the economic crisis have overshadowed everything else" (Barroso 2013, 7). Consequently, the significance of enlargement has decreased at the bottom of the priority list. More concrete, the topic of enlargement was absent from the European Council agenda from 2014 to 2017 (Elena 2019). The accession idea was kept alive by the member states outside of the EU institutional framework. However, the initiatives of Germany and the UK in 2014 have been supported by the Commission. The position changed eventually in 2017 when the former Head of the Commission mentioned the importance of enlargement in his State of the Union speech (Juncker 2017). The change was justified by the argument that the EU position in the Balkans is threatened by competing actors, but the success remained rather limited because of the lack of agreement among the EU member states about the importance of enlargement.

The absence of the EU from the Balkans has also contributed to democratic backsliding in the region and it did allow other actors to impact politics in these countries. The EU enlargement policy in this period was led by the false assumption of the sufficiency of a formal membership perspective for the Western Balkan states. The sufficiency assumption was also because of the reluctant positions of the member states towards enlargement because the whole process is member states dependent. Put it differently, the ability of the European Union to pursue a successful enlargement politics is determined by the member states. This is also why EU politics appears to be inconsistent with Western Balkans. The issue has become evident when France and Netherlands blocked the start of the accession negotiations with Albania and North Macedonia. This is especially true for North Macedonia after the country accepted a decadeslong dispute by changing its name. 
The other side of the coin is the Western Balkans. This refers to the inability of the Western Balkans states to fulfill the requirements set by the EU. The decision of the EU officials to focus rather on security issues and to a lesser extent to democratic development contributed to the democratic backsliding (Richter 2012). Moreover, the EU officials circumvented the citizens, in the case of Bosnia, and focused on the political elites (Džihić and Wieser 2011, 1804). By negotiating with the elites, without the involvement of citizens, the acts of the elites are practically legitimized by the European officials.

A successful enlargement politics requires notable changes, both in the EU and the Balkans. The changes imply concrete actions that go beyond the rhetoric commitments of all sides involved.

\section{CONCLUSION}

The enlargement politics of the European Union is member states dependent because of formal requirements of all states to vote for the accession. This work compared the positions of the two leading countries in the European Union, France, and Germany. French position concerning enlargement is reluctant. In the past enlargement rounds, France has only unwillingly accepted the accession of new states. Germany, on the other side, follows a policy that is more welcoming for new enlargements.

First, the positions of both states represent a constant. The official stands are based on different ideas of these two countries about the nature of the EU and the path it should take in the integration process. Both countries support the further deepening of the Union, which includes a strong global actor. French idea is to have a several-speed Europe with enhanced cooperation among states within the block (Macron 2017). The German idea is a strong Europe with an increased ability to act.

The perceptions of the enlargement are based on different calculations of perceived costs and benefits. French government assumes that following the enlargement policy on Western Balkans is costlier than it provides benefits. This is connected to the legal obligation of holding a referendum about the accession of any new states, which can be overridden if 60 percent of the members of both houses of the French Parliament vote for the accession. According to public opinion polls, most of the French citizens reject further enlargement. Thus, the threshold for accession is high. The French position is further constrained by the right-wing populist political party National Rally. By raising the question of enlargement in public, the National Rally can capitalize on the issue by blaming the government for not acting on behalf of the will of the people.

The German position is less constrained compared to the French. German Constitution does not envisage holding a referendum regarding enlargement, while the traditional parties are committed to the EU, and they support the enlargement process. Germany has strong economic ties to Western Balkan states, which is an additional argument to support the accession. In short, the perception of the German government is that the benefits of the enlargement process outweigh the costs. Perceived benefits are to a large extent the stability in the region and to a lesser extent the economic benefits. 


\section{REFERENCES}

AfD. 2021. "Deutschland. Aber Normal. Programm Der Alternative Für Deutschland Für Die Wahl Zum 20. Deutschen Bundestag." : 210. https://www.afd.de/wpcontent/uploads/sites/111/2021/06/20210611_AfD_Programm_2021.pdf.

Agence Française de Développement. 2021. AFD and the Western Balkans. https://www.afd.fr/en/ressources/afd-and-westernbalkans?origin=/en/rechercher?query=balkans.

Alternative für Deutschland. 2014. Mut Zu Deutschland. Für Ein Europa Der Vielfalt. http://www.afdbayern.de/wp-content/uploads/sites/86/2014/12/Europaprogramm-derAfD1.pdf (March 15, 2017).

Attalai, Chafika, and Dahina Moussi. 2021. "Islamophobia in France: National Report 2020." In European Islamophobia Report 2020, eds. Enes Bayraklı and Farid Hafez. Vienna: Leopold Weiss Institute, 297-352.

Azrout, Rachid, Joost Van Spanje, and Claes de Vreese. 2012. "When News Matters: Media Effects on Public Support for European Union Enlargement in 21 Countries." JCMS: Journal of Common Market Studies 50(5): 691-708.

https://onlinelibrary.wiley.com/doi/abs/10.1111/j.1468-5965.2012.02255.x.

Banchoff, Thomas. 1997. "German Policy towards the European Union: The Effects of Historical Memory." German Politics 6(1): 60-76.

https://doi.org/10.1080/09644009708404464.

Barroso, José Manuel. 2013. "State of the Union Address 2013.” http://europa.eu/rapid/pressrelease_SPEECH-13-684_en.htm (May 14, 2019).

Bieber, Florian. 2018. "Patterns of Competitive Authoritarianism in the Western Balkans." East European Politics 34(3): 337-54. https://doi.org/10.1080/21599165.2018.1490272.

Bulmer, Simon. 2014. "Germany and the Eurozone Crisis: Between Hegemony and Domestic Politics.” West European Politics 37(6): 1244-63.

https://doi.org/10.1080/01402382.2014.929333.

CDU/CSU. 2013. "Gemeinsam Erfolgreich Für Deutschland. Regierungsprogramm 2013 2017." https://www.bundestagswahl-bw.de/wahlprogramm_cdu-csu.html.

_. 2021. "Das Programm Für Stabilität Und Erneuerung."

https://online.fliphtml5.com/kxyi/eyjg/\#p=20.

Die Gruene. 2021. "Deutschland. Alles Ist Drin. Bundestagswahlprogramm 2021." https://cms.gruene.de/uploads/documents/Wahlprogramm-DIE-GRUENEN-Bundestagswahl2021_barrierefrei.pdf.

Die Zeit. 2017. “SPD: Schulz Will Vereinigte Staaten von Europa Bis 2025.” Die Zeit. http://www.zeit.de/politik/deutschland/2017-12/spd-martin-schulz-parteitag-rede-grossekoalition (January 6, 2018). 
Dreger, Christian. 2017. "Der Wirtschaftliche Nutzen Europas Für Deutschland.” In Handbuch Zur Deutschen Europapolitik, eds. Karin Böttger and Mathias Jopp. Bonn: Bundeszentrale für politische Bildung, 77-90.

Dursun-Ozkanca, Oya. 2013. "French Public Opinion on the European Union's Eastern Enlargement and Public-Elite Relations.” French Politics 11(3): 241-58.

Džihić, Vedran, and Angela Wieser. 2011. "Incentives for Democratisation? Effects of EU Conditionality on Democracy in Bosnia \& Hercegovina." Europe-Asia Studies Vol 63(10): 1803-25. https://doi.org/10.1080/09668136.2011.618681.

Elena, Anghel Suzana. 2019. "European Council in Action Western Balkans : State of Play in the European Council Overview of Discussions since the Lisbon Treaty." (October): 12. http://www.europarl.europa.eu/RegData/etudes/BRIE/2018/615678/EPRS_BRI(2018)615678 _EN.pdf (February 4, 2019).

Emmott, Robin. 2021. "EU No Longer Agrees on Balkan Membership Guarantee, Diplomats Say." Reuters. https://www.reuters.com/world/europe/eu-no-longer-agrees-balkanmembership-guarantee-diplomats-say-2021-09-28/ (November 19, 2021).

European Commission. 2018. "Trade Relations EU-Western Balkans - Product - Eurostat." https://ec.europa.eu/eurostat/web/products-eurostat-news/-/EDN-20180517-

1 ? inheritRedirect=true $($ March 3, 2020).

- 2019. Standard Eurobarometer 91 - First Results.

https://europa.eu/eurobarometer/api/deliverable/download/file?deliverableId=70922.

European External Action Service. 2016. Shared Vision, Common Action: A Stronger Europe. A Global Strategy for the European Union's Foreign And Security Policy. Brussels. https://eeas.europa.eu/archives/docs/top_stories/pdf/eugs_review_web.pdf.

Eurostat. 2021. Demographic Developments in the Western Balkans and Turkey. 2021 Edition. https://ec.europa.eu/eurostat/documents/4031688/12964134/KS-02-21-839-ENN.pdf/c28bc490-eba4-8f8f-c368-40ad7b68c968?t=1624974063259.

Focus Online. 2014. "10 Jahre Beitritt Der Ost-Staaten: EU-Erweiterung Brachte Deutschland Eine Million Jobs.” Focus Online. https://www.focus.de/finanzen/news/10-jahre-beitritt-derost-staaten-eu-erweiterung-brachte-eine-millionen-jobs-fuer-deutschland_id_3808970.html (December 12, 2019).

French Government. 2019. "Non-Paper: Reforming the European Union Accession Process." https://www.politico.eu/wp-content/uploads/2019/11/Enlargement-nonpaper.pdf.

French National Assembly. 1958. "French Constitution."

German Federal Government. 2014. "Final Declaration by the Chair of the Conference on the Western Balkans, Berlin, 28 August 2014.” Pressemitteilung.

https://www.bundesregierung.de/resource/blob/997532/754648/8ee38f8caff4ce3fd83fa0dea9b 19b8e/2014-08-28-erklaerung-westbalkankonferenz-eng-data.pdf?download=1 (December 6, 2018). 
2016. "White Paper 2016 on German Security Policy and the Future of the

Bundeswehr." : 144.

https://www.bmvg.de/resource/blob/13708/015be272f8c0098f1537a491676bfc31/weissbuch2 016-barrierefrei-data.pdf.

Große Hüttmann, Martin. 2017. "Leitbilder Deutscher Europapolitik.” In Handbuch Zur Deutschen Europapolitik, eds. Karin Böttger and Mathias Jopp. Bonn: Bundeszentrale für politische Bildung, 31-44.

Hameleers, Michael, Linda Bos, and Claes de Vreese. 2017. "Framing Blame: Toward a Better Understanding of the Effects of Populist Communication on Populist Party Preferences.” Journal of Elections, Public Opinion and Parties 28(3): 380-98. https://doi.org/10.1080/17457289.2017.1407326.

Jeřábek, Martin. 2011. "Deutschland, Zentraleuropa Und Die Osterweiterung Der Europäischen Union.” In Deutschland Und Die Osterweiterung Der Europäischen Union, Wiesbaden: VS Verlag für Sozialwissenschaften, 81-105. https://doi.org/10.1007/978-3-53192792-3_4.

Juncker, Jean Claude. 2017. "President Jean-Claude Juncker's State of the Union Address 2017.” http://europa.eu/rapid/press-release_SPEECH-17-3165_en.htm.

Kaniok, Petr, and Vít Hloušek. 2016. "Euroscepticism and the Prospects of Future Enlargement of the EU." In Paper Prepared for the 8th Pan-European Conference on the European Union: "The Union's Institutional and Constitutional Transformations: Stress or Adaptation?," University of Trento, 1-17.

Krotz, Ulrich. 2015. History and Foreign Policy in France and Germany. London: Palgrave Macmillan.

Krotz, Ulrich, and Joachim Schild. 2013. Shaping Europe : France, Germany, and Embedded Bilateralism from the Elysée Treaty to Twenty-First Century Politics. 1st ed.. Oxford: Oxford University Press.

Kundnani, Hans. 2011. "Germany as a Geo-Economic Power." The Washington Quarterly 34(3): 31-45. https://doi.org/10.1080/0163660X.2011.587950.

Lippert, Barbara. 2007. "Alle paar Jahre wieder - Dynamik und Steuerungsversuche des EUErweiterungsprozesses." integration 30(4): 422-39. https://doi.org/10.5771/0720-5120-2007$4-422$.

_. 2017. "Die Bundesrepublik Deutschland Und Die Erweiterung Der Europäischen Union.” In Handbuch Zur Deutschen Europapolitik, eds. Katrin Böttger and Mathias Jopp. Bonn: Bundeszentrale für politische Bildung, 393-406.

Macron, Emmanuel. 2017. "Initiative for Europe Speech by M. Emmanuel Macron, President of the French Republic."

https://www.diplomatie.gouv.fr/IMG/pdf/english_version_transcript__initiative_for_europe_-_speech_by_the_president_of_the_french_republic_cle8de628.pdf. Marks, Gary, and Liesbet Hooghe. 2009. “A Postfunctionalist Theory of European 
Integration: From Permissive Consensus to Constraining Dissensus." British Journal of Political Science 39(1): 1-23.

http://www.journals.cambridge.org/abstract_S0007123408000409.

Moravcsik, Andrew, and Milada A Vachudova. 2003. "National Interests, State Power, and EU Enlargement." East European Politics and Societies 17(1): 42-57.

http://eep.sagepub.com/cgi/doi/10.1177/0888325402239682.

Mudde, Cas. 2004. "The Populist Zeitgeist." Government and Opposition 39(4): 541-63. https://onlinelibrary.wiley.com/doi/abs/10.1111/j.1477-7053.2004.00135.x.

Münkler, Herfried. 2017. "Deutsche Hegemonie in Europa? Über Die Rolle Und Aufgaben Einer 'Macht in Der Mitte."' In Europas Ende, Europas Anfang. Neue Perspektiven Für Die Europäische Union, eds. Jürgen Rüttgers and Frank Decker. Bonn: Bundeszentrale für politische Bildung, 103-16.

Pere, Engjëll, and Eniel Ninka. 2017. International Trade in Western Balkan Countries: Analysis Based on the Gravity Model. Vienna. https://wiiw.ac.at/international-trade-inwestern-balkan-countries-analysis-based-on-the-gravity-model-p-4632.html.

Politico. 2018. "Macron Pours Cold Water on Balkan EU Membership Hopes.” Politico. https://www.politico.eu/article/emmanuel-macron-pours-cold-water-balkans-eu-membershipenlargement/ (May 25, 2018).

- 2021. "France — 2022 Presidential Election Voting Intention.” Poll of Polls. https://www.politico.eu/europe-poll-of-polls/france/ (November 24, 2021).

Richter, Solveig. 2012. "Two at One Blow? The EU and Its Quest for Security and Democracy by Political Conditionality in the Western Balkans." Democratization 19(3): 50734. https://doi.org/10.1080/13510347.2012.674360.

Rieker, Pernille. 2005. French Foreign Policy and the Limits of Europeanisation: The Changing French Position on EU Enlargement. Norwegian Institute of International Affairs. https://nupi.brage.unit.no/nupixmlui/bitstream/handle/11250/2395417/WP_nr692_05_Rieker.pdf?sequence=3\&isAllowed= y.

Roth, Michael. 2018. "Der Westbalkan Ist Europas Innenhof.” Frankfurter Allgemeine Zeitung: 10. https://www.auswaertiges-amt.de/de/newsroom/roth-frankfurterallgemeine/2102814.

Schimmelfennig, Frank. 2005. "The Community Trap: Liberal Norms, Rhetorical Action, and the Eastern Enlargement of the European Union." In The Politics of European Union Enlargement: Theoretical Approaches, eds. Frank Schimmelfennig and Ulrich Sedelmeier. London; New York: Routledge, 142-66.

Sedelmeier, Ulrich. 2005. "Eastern Enlargement: Risk, Rationality and Role-Compliance.” In The Politics of European Union Enlargement: Theoretical Approaches, eds. Frank Schimmelfennig and Ulrich Sedelmeier. London; New York: Routledge, 120-37. Sjursen, Helene, and Børge Romsloe. 2006. "Protecting the Idea of Europe. France and 
Enlargement." In Questioning EU Enlargement: Europe in Search of Identity, ed. Helene Sjursen. London; New York: Routledge, 142-62.

Skalnes, Lars S. 2005. "Geopolitics and the Eastern Enlargement of the European Union." In The Politics of European Union Enlargement Theoretical Approaches, eds. Frank Schimmelfennig and Ulrich Sedelmeier. London; New York: Routledge, 213-33.

SPD/Gruene/FDP. 2021. "Mehr Fortschritt Wagen. Bündnis Für Freiheit, Gerechtigkeit Und Nachhaltigkeit." https:/fr.de/content/fr/downloads/pdf/koalitionsvertrag-2021-2025.pdf.

SPD. 2013. "Das Wir Entscheidet. Das Regierungprogramm 2013 - 2017." https://www.spd.de/fileadmin/Dokumente/Beschluesse/Bundesparteitag/20130415_regierungs programm_2013_2017.pdf.

. 2017. "Zeit Für Mehr Gerechtigkeit. Unser Regierungsprogramm Für Deutschland." https://www.spd.de/fileadmin/Dokumente/Regierungsprogramm/SPD_Regierungsprogramm_ BTW_2017_A5_RZ_WEB.pdf.

—. 2021. “Aus Respekt Vor Deiner Zukunft. Das Zukunftsprogramm Der SPD.” https://www.spd.de/fileadmin/Dokumente/Beschluesse/Programm/SPD-

Zukunftsprogramm.pdf.

Steinmeier, Frank-Walter. 2015. “Zur „DNA“ Der Deutschen Außenpolitik.” Internationale Politik und Gesellschaft. https://www.ipg-journal.de/rubriken/aussen-undsicherheitspolitik/artikel/zur-dna-der-deutschen-aussenpolitik-810/ (January 30, 2019).

Steinmeier, Frank-Walter, and Philip Hammond. 2014. "Ein Neustart Für Bosnien Und Herzegowina." Frankfurter Rundschau: 12.

Süddeutsche Zeitung. 2019. "Belohnung Für Den Balkan - Politik.” Sueddeutsche.de. https://www.sueddeutsche.de/politik/eu-beitritt-balkan-nordmazedonien-albanien-1.4467840 (October 29, 2019).

Szołucha, Anna. 2010. "The EU and Enlargement Fatigue: Why Has the European Union Not Been Able to Counter Enlargement Fatigue?" Journal of Contempirary European Research Vol 6(1): 1-16.

Toeglhofer, Theresia, and Cornelius Adebahr. 2017. "Firm Supporter and Severe Critic Germany's Two-Pronged Approach to EU Enlargement in the Western Balkans." Southeast European and Black Sea Studies 17(4): 523-39. https://doi.org/10.1080/14683857.2017.1397961.

Topaloff, Liubomir. 2017. "Euroscepticism and Political Parties: Theory and Practice." In The Routledge Handbook of Euroscepticism, Taylor and Francis, 63-74.

Vassallo, Francesca. 2012. "The EU Discourse in the 2012 French Presidential Election." French Politics, Culture \& Society 30(3).

de Vreese, Claes H, and Hajo G Boomgaarden. 2006. "Media Effects on Public Opinion about the Enlargement of the European Union*." JCMS: Journal of Common Market Studies 44(2): 
419-36. http://doi.wiley.com/10.1111/j.1468-

5965.2006.00629.x\%5Cnhttp://onlinelibrary.wiley.com/doi/10.1111/j.1468-

5965.2006.00629.x/abstract.

Wunsch, Natasha. 2017. "Between Indifference and Hesitation: France and EU Enlargement towards the Balkans." Southeast European and Black Sea Studies 0(0): 1-14.

https://doi.org/10.1080/14683857.2017.1390831.

Zúquete, José Pedro. 2016. “The European Extreme-Right and Islam: New Directions?” In The Populist Radical Right: A Reader, ed. Cas Mudde. London: Routledge, 660. 